Article

\title{
The Emergence of Native Podcasts in Journalism: Editorial Strategies and Business Opportunities in Latin America
}

\author{
José Luis Rojas-Torrijos ${ }^{1, *}$, Francisco Javier Caro-González ${ }^{2}$ and José Antonio González-Alba ${ }^{3}$ \\ ${ }^{1}$ Department of Journalism II, University of Seville, 41092 Seville, Spain; E-Mail: jlrojas@us.es \\ 2 Department of Business Administration and Marketing, University of Seville, 41092 Seville, Spain; E-Mail: fjcaro@us.es \\ 3 University of Cádiz, 11000 Cádiz, Spain; E-Mail: joseantonio@sembramedia.org \\ * Corresponding author
}

Submitted: 10 December 2019 | Accepted: 29 January 2020 | Published: 16 April 2020

\begin{abstract}
This article analyses the state of the art of podcasting in the new digital landscape as well as the structures, editorial strategies, and business models of native podcasts launched in Latin America over the last few years. To this end, a multiple case study has been made to examine the way new digital outlets are using audio content. This qualitative research is made up of a variety of approaches, such as interviews, online surveys of podcasters, as well as the collection and analysis of secondary data. A specific aim of this comparative study was to include a sample of podcasts produced by thirteen emerging media platforms from eight countries registered in the directory of digital natives conducted by SembraMedia (https://www.sembramedia.org). This is a nonprofit organization dedicated to increasing the diversity and quality of Spanish language content by helping digital media entrepreneurs become more sustainable and successful. Results of this exploratory study reveal that native podcasting in Spanish is still expanding and that where the new media are small in scale, they are more oriented to the full exploitation of the narrative and innovative possibilities of this audio format and do not have responding to their target audiences' needs as their main priority. These new media are finding different ways to become monetised (mainly content production for clients, sponsored content, sponsorship, consulting services, and advertising) and to make a profit.
\end{abstract}

\section{Keywords}

business models; digital native news media; entrepreneurial journalism; online journalism; podcasting

Issue

This article is part of the issue "Digital Native News Media: Trends and Challenges" edited by Ramón Salaverría (University of Navarra, Spain).

(C) 2020 by the authors; licensee Cogitatio (Lisbon, Portugal). This article is licensed under a Creative Commons Attribution 4.0 International License (CC BY).

\section{Introduction}

In the era of multi-platform distribution, fragmented audiences, and the spread of content through social media, digitalization has bolstered new forms of doing journalism which aim to deliver news to audiences as fast and efficiently as possible. The so-called "new media" (Cabrera, Codina, \& Salaverría, 2019) have not only been able to adapt themselves to the new scenario but also to be seen as an alternative to traditional news outlets (Harlow \& Salaverría, 2016). These digital jour- nalistic platforms, also known as "digital native media" (Salaverría \& Negredo, 2013, p. 175), provide easier access from any device globally, and produce instant, interactive, and multimedia content clearly oriented to the users' information needs (Pavlik, 2001, p. XI).

But media convergence-a process to reduce the cost of information production and to improve the accessibility and popularity of digital platforms (Jenkins, Ford, \& Green, 2015; Quinn, 2006)-is what truly defined the notion of the active audiences within today's media industries and blurred the boundaries between production 
and consumption of news (Schanke \& Ytreberg, 2009). Likewise, the growing presence of prosumers in the media flow and the emergence of independent media operators have compelled legacy media to search for new journalistic strategies, formats, and narratives similar to those being developed by the new media.

In this context, podcasts have gained popularity among users and have aroused increasing interest within media outlets as news consumption on mobile devices has grown, and listening to linear radio has been disrupted by the rise of on-demand technology (Newman, 2018a). In fact, podcasting represents a "rupture of the traditional concepts of transmission-reception and synchrony" (Salgado, 2010, p. 136) in favour of portability, interaction, and the freedom to listen to any content.

Producing podcasts, as encapsulated audio files for download to be played on any device at any time, implies the involvement of an active audience who feels empathy with specific content and even "a higher level of complicity between the producer and the listener" (González-Alba, 2018). So, as Moreno-Cazalla (2017, p. 337) points out, changes in reception processes, the new time-space paradigm, and the content customisation are the key elements that explain the boom in podcasting. The rise of personal narratives, "intrinsically linked to the intimate nature of the audio medium" (Lindgren, 2016, p. 24), is one of journalistic storytelling's newest forms of innovation in to reach new audiences.

The evolution of this audio format, whose roots date back to 2001 (Sellas, 2011, p. 11) and which came of age in 2004, has been relentless. After an initial stage where podcasts were more radiogenic (Berry, 2006) and were mainly produced by amateurs (McClung \& Johnson, 2010), these formats became "a distinct medium" (Berry, 2016, p. 1) or "a digital mass medium" (Bonini, 2015, p. 23) considering the manner in which they are produced and consumed. Since then, podcasts have quietly grown year by year, both in terms of producers and listeners: "It was estimated that in 2013 there were well over 250,000 unique podcasts in more than 100 languages available online" (Bottomley, 2015).

There are two main reasons for this development: the increasing interest in the podcast market by online platforms and tech giants such as Apple, Spotify, and Google, which "have begun making major investments in the medium" (Sullivan, 2019, p. 9); and the exponential growth in the number of mobile devices among the population. According to the Global Digital Report 2019 (We Are Social \& Hootsuite, 2019), the amount of smartphone users increases by $2 \%$ per year and the almost 4,000 million active mobile users in the world already spend half of their time on these small screens searching for information on the Internet. This fact is even clearer in the youngest age groups who definitely seem to have abandoned analogue radio (Pedrero, Barrios, \& Medina, 2019).

In this new scenario, radio operators have been forced to assume that news consumption habits have changed forever and, consequently, they have had to invest more in digital audio in order to rethink their content production and delivery routines. In this sense, the increasing interest in podcasting turns out to be "like a second life" for radio programmes in digital environments (Sánchez, 2017, p. 158).

Different studies reflect this trend in the media industry. The Digital News Report 2018 published by the Reuters Institute for the Study of Journalism indicates that more than a third of people interviewed had listened to a news-related podcast at least monthly although there was significant national variation. While in some Asia territories, podcasts are listened to by more than $55 \%$ of people, this audio format seems to be "least accessed in European countries with a strong audio tradition" such as the United Kingdom or the Netherlands, both with only $18 \%$ of listeners (Newman, 2018b).

This annual report also underlines how media outlets are employing this format as a way to directly connect with younger audiences, especially those under 35 . This age group marks a clear division between the generation who prefers to consume podcasts and older listeners who "are twice as likely to consume traditional radio news" (Newman, 2019b). Some legacy media try to bridge the gap between "the new and the old" audiences by maintaining a balance in their content production and by working across all digital platforms (Lindeberg, 2019, p. 23).

Meanwhile, traditional journalistic brands are making a great effort to adapt themselves to the digital landscape and there has been a meteoric rise of new digital media or native cyber media (Salaverría, 2019). These projects stand out for having a diverse number of channels, formats, narratives, business models, and relationships with users (Toural \& López, 2019). Some of these digital-native outlets chose podcasts as their sole (or main) production platform, which suggest that some quality attributes and journalistic consumption patterns are quite different to the legacy media production (Arrese \& Kaufmann, 2016).

Among those quality attributes linked to podcasts is personal branding for journalists. Previous research studies have highlighted the rise in native podcasts produced by experienced professionals who are making good use of this format to boost their personal brands, as happened to blogs some years ago (Demopoulos, 2006, p. 131). In this regard, López-Meri and Casero (2017) consider the creation of a personal brand as an ongoing process in which journalists take advantage of digital platforms, mainly social media networks, to show who they are, how they work, to set themselves apart from competitors, and be accepted by users.

Thus, podcasts have become a suitable format for journalists to create and highlight their personal brand and may also serve as a means to target specific audiences, to find a niche, or to engage in "hyper specialised" journalism (Rojas-Torrijos, 2018). In an era of increasing fragmentation of public attention across digital plat- 
forms (Masip, Ruiz-Caballero, \& Suau, 2019; Webster \& Ksiazek, 2012), news podcasts may respond to specific information needs of audience segments who are not being properly informed by the generalist media.

Some studies have examined the patterns and motivations of podcast users and indicate two trends. On the one hand, audiences, even young people, are listening to podcasts that entertain and inform (Newman, 2019b, p. 62). This may explain why publishers are making investments in news podcasts, popularised in 2017 following the success of The Daily by The New York Times (Verdier, 2018). News podcasts have been defined as "regularfrequency multi-platform and on-demand podcasts produced by big media outlets to provide daily coverage of general interest news in a short format that lasts about 3-25 minutes" (Pérez \& Lus, 2019, p. 326) and represent an opportunity for those companies to develop innovative storytelling techniques, build audience habits, and consolidate their brands.

On the other hand, one of the main motivations of using podcasts instead of linear radio includes developing audience interest into specific topics. Apart from suggesting that entertainment is the major motivation to choose the digital audio (McClung \& Johnson, 2010) and that music is the most consumed type of media content (Edison Research, 2019), podcasts are appealing to users because they are able to attend to the personal interests of each user (Newman, 2019b), such as leisure, food, health, technology, or sports (Newman, 2018b). As a consequence, the range of podcasts is as wide as it is diverse, which explains the rapid development of this format (Sellas, 2011, p. 28).

Considering these motivations, those native news podcasts that are focused on specific topics or niche products seek competitive advantage by reaching and taking care of target audiences and then by drawing the attention of advertisers or clients to become profitable.

For entrepreneurs and independent podcasts producers, the monetization of the news product is essential. However, there are still too many open questions around the implementation and the public acceptance of payment models in the podcast industry. While this model is well established in countries that have a long tradition in podcasting such as the United States or the United Kingdom (Newman \& Gallo, 2019; Sellas, 2011), in other markets such as Spain this journalistic product probably needs more time. The number of podcasts that are financially viable is still an exception in this country (Rouco, 2019).

The production of quality content in podcasts, the potential for niche journalism in this format, the opportunities for entrepreneurs, and the harmonisation of all this with an adequate business model shapes an ongoing debate on a sector that still is in its development stage. It will, therefore, be necessary to address the study of concrete cases to analyse the viability and potential of native podcasts in journalism.

\section{The Study}

Regarding this context, this article analyses the state of the art of native news podcasts launched in Latin America in recent years. In this research, we consider 'native' podcasts as those created solely for digital-only platforms and promoted by entrepreneurs or independent companies not associated with big media brands. Also, following the abovementioned authors Bonini (2015) and Berry (2016), we regard those news podcasts produced by audio-only or audio-first outlets as digital media themselves.

To this end, a multiple case study has been made to examine the way audio content is being used by new digital outlets in Spanish speaking countries. Although these markets still do not have the same level of development as in Anglo-Saxon countries, Latin America emerges as the area where the consumption of podcasts is growing faster. This is pointed out in the report published by Voxnest in the first quarter of 2019: Chile, Argentina, Peru, and Mexico, in this order, are the four countries with the highest predicted levels of podcast growth globally (Grey, 2019). This same report in 2018 highlighted a $13 \%$ yearon-year increase in the production of digital audio in Latin America and noted that Spanish language podcasts in are improving in quality and becoming more professional and diverse, thanks in part to the expansion of large platforms such as Spotify into the area (Voxnest, 2018).

Specific purposes of this comparative study include a sample of podcasts produced by thirteen emerging media platforms from eight countries registered in the directory of digital natives conducted by SembraMedia (https://www.sembramedia.org). This is a nonprofit organization dedicated to increasing the diversity and quality of Spanish language content by helping digital media entrepreneurs become more sustainable and successful. Since its foundation in 2015, SembraMedia has mapped the digital media ecosystem in Latin America, Spain, as well as the Spanish speaking news outlets in the United States, and has built a regional network made up of more than 800 new media.

Latin America is still an outlying area in journalism studies and, more specifically, in Anglo-Saxon academic journals, which have been criticised for the lack of racial, national, and ethnic diversity within their editorial boards, topics, and authors (Usher, 2019). Meanwhile, the Spanish-speaking subcontinent emerges as a land of opportunity for digital entrepreneurs who are playing an increasingly important role in terms of innovation in journalism (SembraMedia, 2017, p. 6).

\subsection{Hypothesis and Objectives}

News native podcasts are still in an early phase of expansion and experimentation in Latin America and are an area of interest among entrepreneurs, who search for opportunities for profit within the media sector while the number of direct competitors is still low. 
With this hypothesis in mind, the objectives of this multiple case study are:

RO1: To understand and evaluate the relevance of the creation and development of podcasts in the new media ecosystem and to explore the degree of journalistic entrepreneurship reached by this audio platforms in Spanish language;

RO2: To know the strategic planning approaches adopted by the promoters of these emergent journalistic projects in connection with their business missions, their clients and competitors, as well as their value propositions associated with certain contents;

RO3: To analyse the potential of podcasts to boost journalists' personal brands and to move towards niche or hyper specialised journalism in the media industry;

RO4: To examine the main motivations that led entrepreneurs to produce news and other journalistic content in this audio format;

RO5: To know the major revenue sources of the Spanish-language native news podcasts that have become monetised and to explore their financial profitability in both short and medium-term scenarios.

\subsection{Methodology}

We chose a qualitative case study design to respond to the research objectives. A case study design is applicable for identifying emerging themes and patterns as it enables the acquisition of rich and detailed data (Eisenhardt, 1989; Eisenhardt \& Graebner, 2007; Miles \& Huberman, 1994). Multiple cases are investigated to provide more accurate, generalisable, and robust results (Rowley, 2002; Yin, 2009) and provide a stronger foundation on which to build theories (Yin, 2009).

We chose companies from the SembraMedia database. This directory comprises a sum of 767 digital media (September 2019), although only 80 of them provide any sort of audio format. Finally, we identified which outlets used podcasts as their main or only platform to produce and disseminate news, and obtained a sample of 20 media. We contacted all of them, but only 13 responded to our requests (Table 1 ).

We truly believe that this sample is appropriate for the goals of this exploratory research. Previous case study research in Social Sciences accepts that the number of participants may range between a minimum of 4 and a maximum of 10 according to the degree of thoroughness in the exploration (Eisenhardt, 1989; Rowley, 2002). To better conduct an in-depth analysis and an extensive collection of data for any organisation it is even advisable to take a limited number of cases (Yin, 2009).

Table 1. Native podcasts studied from SembraMedia database.

\begin{tabular}{|c|c|c|c|c|}
\hline Name & Country & Economic Aim & Length of Service & Other platforms \\
\hline Revista 070 & Colombia & Nonprofit & $>3$ years & Website \\
\hline Coloquio & Puerto Rico & Nonprofit & $>3$ years & $\begin{array}{l}\text { App, Facebook, Twitter, YouTube, } \\
\text { Vimeo }\end{array}$ \\
\hline Parque Podcast & Argentina & Profit & $2-3$ years & Website, Facebook, Twitter \\
\hline Las Raras Podcast & Chile & Nonprofit & $>3$ years & $\begin{array}{l}\text { Website, Facebook, Twitter, } \\
\text { YouTube, Vimeo }\end{array}$ \\
\hline Libertarias & Dominican Republic & Nonprofit & $<1$ year & Facebook, Radio online, Instagram \\
\hline Wetoker & Argentina & Profit & $>3$ years & $\begin{array}{l}\text { Website, Newsletter, Facebook, } \\
\text { Twitter, Instagram }\end{array}$ \\
\hline Los Puentes Digitales & Spain & Profit & $>3$ years & $\begin{array}{l}\text { Website, App, Facebook, Twitter, } \\
\text { YouTube, Vimeo, Patreon }\end{array}$ \\
\hline Latitud 25 & Paraguay & Profit & $>3$ years & $\begin{array}{l}\text { Website, TV, Facebook, Radio online, } \\
\text { Twitter, YouTube, Vimeo }\end{array}$ \\
\hline Akorde Podcast & Colombia & Profit & $>3$ years & $\begin{array}{l}\text { Website, Blog, Newsletter, } \\
\text { Facebook, Radio online, Twitter }\end{array}$ \\
\hline Posta & Argentina & Profit & $>3$ years & $\begin{array}{l}\text { Website, Facebook, Twitter, } \\
\text { Instagram }\end{array}$ \\
\hline Grupo Naranja Media & Colombia & Profit & $>3$ years & Blog \\
\hline Relato Nacional & Chile & Profit & $>3$ years & Website, Facebook, Twitter \\
\hline UyCast & Uruguay & Profit & $1-2$ years & $\begin{array}{l}\text { Website, Facebook, Twitter, Blog, } \\
\text { Instagram }\end{array}$ \\
\hline
\end{tabular}

Source: SembraMedia (2019). 
As a matter of fact, case study samples do not exactly represent a concrete universe of participants, so that the results obtained will not show the validity of the statistical representativeness and, consequently, should not be extended as a general rule for an entire population. This approach involves understanding the characteristics of a phenomenon in its context in such a way that the analytical findings are more widely applicable (Hartley, 1994). Gummesson (2000) suggests that this qualitative method seeks to comprehend processes, to provide frameworks, and to identify driving forces rather than to determine exact cause-and-effect correlations.

We interviewed the podcast providers from the SembraMedia database. They were asked about their business missions, their clients and competitors, their value proposals associated with certain contents, and the main reasons that they chose to use podcasts.

Likewise, they received an online survey by email, later reinforced via telephone, Twitter, and Facebook. The closed-ended questions were intended to learn more about their business models, the monetisation of the projects, and, more specifically, expenditure items and revenue sources.

The information gathered from the answers in the interviews and the survey was finally completed with the lookup on the SembraMedia database and on the platforms of each project.

The fieldwork was conducted in 2019, between October and November. The qualitative information obtained has been handled with the data analytics software ATLAS.ti (version 8).

To develop a more accurate data analysis with ATLAS.ti, all the questions were categorised and codified. The function "wordcruncher" was applied to explore each category/question so as to identify the most commonly used terms and expressions in their replies. Any relevant word or phrase was automatically codified in a news process to compare the qualitative results. The coding system was built by combining codes derived from both theory and data analysis. The codes used in this research are the ones identifies in Figure 1.

\section{Results}

The native news podcasts are still small in scale. None of the cases studied has been promoted just by one person. The average number of entrepreneurs is three people per podcast, with $44 \%$ being women. Regarding the staff, these projects have an average of 4.2 employees and a significant percentage of women (50\%).

This last percentage may imply that the new media companies are making efforts to balance the participation of male and female reporters in the production of news. This fact becomes especially relevant in journalism, which is still a male-biased sector where women usually have difficulty gaining positions of responsibility within the companies (Caro-González, García-Gordillo, \& Bezunartea, 2014; De Vuyst \& Raeymaeckers, 2017; Djerf-Pierre, 2007).

Besides, the presence of female journalists in native podcasts is slightly higher than in the rest of the media entrepreneurships in Latin America, where only $40 \%$ of the founding members are women (SembraMedia, 2017, p. 9).

\subsection{The Description of the Organisations}

First of all, the promoters of native podcasts were asked to give a brief description of their organisations. To describe a project is important to take into account the essential elements for any entrepreneur. As a general rule, they have to answer three questions: "What are we doing? For whom? And How?" (Caro-González, 2007, pp. 92-93).

The first question may result in two possible outcomes: the traditional product-oriented strategy, in which they basically explain the format; and the marketoriented approach, where they plan the project according to news demands from certain audiences. 11 out of the 13 studied media referred to the product-"creation, production, and delivery of podcasts" (Akorde Podcast interview)-while just 7 mentioned clients and their needs: "We seek to educate through the stories" (Grupo Naranja Media interview), or "to bridge the gap between

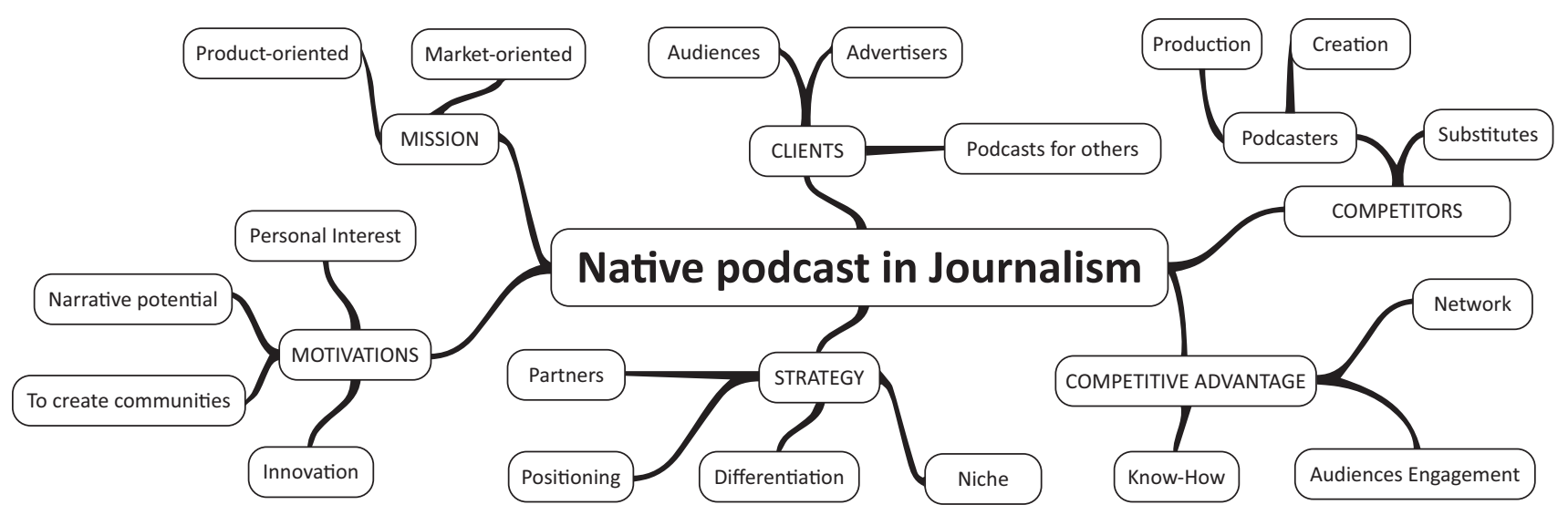

Figure 1. Conceptual map of codes. Source: Author's analysis. 
academic research and new forms of storytelling in journalism practice" (Revista 070 interview).

Concerning the 'For whom' question, 4 out of the 13 new media keep their clients in mind when they describe their projects, even profiling the different markets in which they operate: listeners, advertisers, and thirdparty production entities. UyCast, for instance, identifies "other media or organisations and original production for advertising companies" as clients (UyCast interview).

They also refer to basic intangible aspects such as the importance of the culture and values of the organisation. Just three of the projects underline that they create content from a new and independent approach: "Alternative information about politics, culture, gender, and news" (Latitud 25 interview) or "against algorithms" (Wetoker interview).

Some of the promoters also include references to some distinguishing features of their projects, such as the geographical spread and the brand positioning: "We are the first podcast network in the city of Cordoba, Argentina" (Parque Podcast interview).

In general, these native podcasts are clearly more product-oriented and do not have meeting the specific news demands of their audiences as the main priority. The people interviewed explain what they do but not for whom they do it or why.

\subsection{Clients}

The second open question addressed to the promoters was about their clients. 11 out the 13 cases mention their audiences as clients, 4 refer to advertising companies, and 5 specify other organisations for whom they produce podcasts.

The data they gather from their audiences are highly uneven. Relato Nacional provides information on their listeners by gender and age: "Gender: women $54 \%$, men $44 \%$. Age: $36 \%$ between 28 and 34 years old, $22 \%$ between 35 and 44, 21\% between 23 and 27, 10\% between 45 and 59, 9\% between 18 and 22" (Relato Nacional interview). Nevertheless, other cases such as Coloquio do not yet have any data because it is not provided by their hosting platform.

In general, these native podcasts target young listeners, those aged up to 35 . The highest level of detail in the definition of the audience comes from Posta: "It is gender-balanced, the core is between 25 and 35, mobile, permanently connected, online buyer, pay subscriber, niche consumer, willing to spend time on content they are keen on" (Posta interview).

Meanwhile, other projects observe that their audiences are being reshaped due to changes in the market caused by the expansion of Spotify in Latin America: "Since that arrival audiences have been growing, changing and becoming more diverse. This is why at this moment we need some more time to rethink our strategy and redefine our target audience" (Wetoker interview).

Regarding the advertising market, the projects do not provide enough information to better identify and quantify their clients: "They are small brands that seek to differentiate themselves" (Parque Podcats interview) or "they match with our brand and audiences' values" (Posta interview). Five of these entrepreneurships state they do not have any advertisers.

Moreover, these new media provide podcast production services for organisations that want to take advantage of this format as part of their content strategy. These clients, ranging from university departments and NGO's to private companies, were identified in 5 out of 13 cases in this study.

\subsection{Competitors}

The state of the competition is one of the key elements to estimate the probability of success of any new media. Likewise, it is a way to determine the extent to which this format commands the attention of entrepreneurs.

In this case study, despite the promoters' perception that, in general, there is a growing interest in the podcast format, promoters scarcely consider that they have competitors. In several cases, when referring to other podcast projects in their markets they state that they are not actually competitors but companies that use the same format to reach different targets: "Those projects found their own voice within this ecosystem so there are no direct competitors for us" (Revista 070 interview); "there is not any podcast with our same approach" (Coloquio interview).

Some projects do mention other native podcasts although they do not explain how they compete against them in advertising resources and audiences. To name a few: Radioambulante (Las Raras Podcast); Segmento radial and Podcast Insumisas (Libertarias); Posta Fm and Parque podcast (Wetoker); Convoy, Así como suena and Dixo (Puentes Digitales); El Surtidor, GEN and AAM (Latitud 25); Radio Ambulante and Las raras podcast, Caseritas, Café con Nata and Con la ayuda de mis Amikas (Relato Nacional); Polenta, Caramba and Dobcast (UyCast). Besides, Posta and UyCast distinguish between production competitors and creation competitors.

However, those projects that do not mention their current competition have become aware of their potential competitors. More specifically, these projects see how there is an increasing number of traditional media outlets "that are breaking into the podcast market" and "even in some cases are the same ones to whom we supply with consultancy and other services" (Posta interview). Grupo Naranja Media considers the podcasts "major competitors are substitute products such as video or blogs because many companies still do not know the audio format well, or its advantages" (interview).

In other words and following Porter's (1980) "broad competitive scope" perspective, podcasting in Latin America is still at an early stage of development but, despite being a differentiated product in a sector with little internal rivalry, the audio format may attract some 
competitive forces, such as new entrants and substitute products, into the market.

\subsection{New Digital Media Advantages}

Once the podcast promoters identified their competitors, they had to explain the characteristics that help their value propositions attract the clients' attention.

Here the answers varied widely. Some of the entrepreneurs regard the strategic alliances and the relationships with clients as their main competitive advantage (Revista 070, Wetoker and Latitud 25 interviews), while others emphasised the specific nature of the project and the niche marketing approach as their strengths (Las Raras Podcast and Los Puentes Digitales interviews). UyCast, for example, underlines "a better engagement with female audiences," while others refer to their brand positioning (Posta interview).

They also mention the added value their podcast provides to certain clients: "It helps create a personal brand and many stakeholders want to take part in this ecosystem to gain value" (Wetoker interview).

Finally, some podcast promoters consider that their strengths are internal aspects related to quality and production processes (Relato Nacional interview). For instance, Grupo Naranja Media refers to "the expertise in a narrative that ensures an audience retention rate higher than $70 \%$, the understanding of the format and the harnessing its advantages to enhance our show" (interview).

Other competitive advantages come from their own staff: the know-how and the professional experience (Los Puentes Digitales and UyCast interviews) or their staff's multidisciplinary education including journalism, technology, and marketing (Akorde Podcast and Posta interviews).

\subsection{Why Podcasting?}

The next question intended to find out the reasons why these entrepreneurs decided to produce podcast content. According to their answers, we identify some intrinsic and extrinsic motivations.

In the first answers, some promoters admit they chose this audio format as a consequence of their personal interest (Revista 070 and Wetoker interviews), while the second answers indicate external aspects that acted as incentives for them, such as trends in the media industry. Some entrepreneurs declare they produce podcasts because it's a new format and it means innovation (Coloquio and Las Raras Podcast interviews).

The most frequent motivation has to do with the narrative potential of podcasts:

- "To explain-without impoverishing-complex issues" (Revista 070 interview);

- "Versatility, production facilities, adaptability, on-demand nature, gratuity and easy delivery" (Parque Podcast interview);
- "To connect feature written stories with the radio world" (Relato Nacional interview);

- "This format is the future for the new opportunities it offers" (Wetoker interview);

- "To reach depth in an entertaining manner in a wide variety of topics" (Grupo Naranja Media interview).

Last but not least, there are some motivations determined by the media market: Podcasts are used because the number of people who listen to this format is growing and, consequently, is an opportunity for them to reach wider audiences (Libertarias and Posta interviews) or to create communities and interact with clients (Los Puentes Digitales and Latitud 25 interviews).

\subsection{Business Models}

Hereafter, the promoters of the new audio platforms were asked about the relevance of certain revenue sources and expenditure items. For this question, we employed a Likert-type scale to offer the respondents five possible quantitative values to weight the importance of income and expenses involved in their respective projects. An average of each revenue source and expenditure item was calculated from the total sum of replies.

For instance, in the case of 'sponsorship' (Table 2), the 13 podcasters gave the following values: $1,2,1,2$, $1,3,1,5,3,1,4,4,4$. The resulting average is 2.46 and the sum of all revenues sources values is 30.49 . Consequently, the real importance of revenue sources is at a rate of $8 \%$.

These answers highlight which streams are key to success in these projects.

Table 2. Revenue sources.

\begin{tabular}{lc}
\hline Revenue Source & Importance (\%) \\
\hline Content production for clients & $12 \%$ \\
Sponsored content & $8 \%$ \\
Sponsorship & $8 \%$ \\
Consulting services & $8 \%$ \\
Advertising & $8 \%$ \\
Subscriptions & $7 \%$ \\
Foundations and grants & $7 \%$ \\
Training services & $6 \%$ \\
Donations & $6 \%$ \\
Events & $6 \%$ \\
Crowdfunding & $5 \%$ \\
Profitable memberships & $5 \%$ \\
Content syndication & $4 \%$ \\
E-commerce & $4 \%$ \\
Government funds & $4 \%$ \\
Pay-per-use & $3 \%$ \\
& $100 \%$ \\
\hline
\end{tabular}

Source: Author's analysis. 
Remarkably, content production for clients, in general, is the main revenue source in the cases studied (Table 2). Six out of the 13 promoters regard this item as their first priority. So, the monetisation of these podcasts is achieved by creating content for private companies or public organisations. The other major revenue sources, in order of importance, are sponsored content, sponsorships, consulting services, and advertising. It can be noted that these new media might run into financial difficulty if they were only able to rely on direct contributions from the audiences (subscriptions, memberships or crowdfunding). It is also noteworthy that these audio platforms need to diversify their incomes to survive.

To supplement the results of the study, the podcasters interviewed were asked to indicate the importance of the different expenditure items in their organisations. Table 3 shows that the largest item of expenditure is the staff and their salaries, ahead of financial costs and the use of digital technologies (network servers and software).

Table 3. Types of expenses.

\begin{tabular}{lc}
\hline Types of Expenses & Importance (\%) \\
\hline Salaries & $17 \%$ \\
Financial costs & $15 \%$ \\
Network servers & $14 \%$ \\
Software & $12 \%$ \\
Others & $12 \%$ \\
Electricity, water, and other supplies & $11 \%$ \\
Office rental & $11 \%$ \\
Depreciation of equipment & $10 \%$ \\
& $100 \%$ \\
\hline
\end{tabular}

Source: Author's analysis.

Finally, the ratio of revenue to expense leads us to ask about the profitability of these projects. As shown in Figure 2, the podcasters interviewed consider their respective platforms as being either already prof-

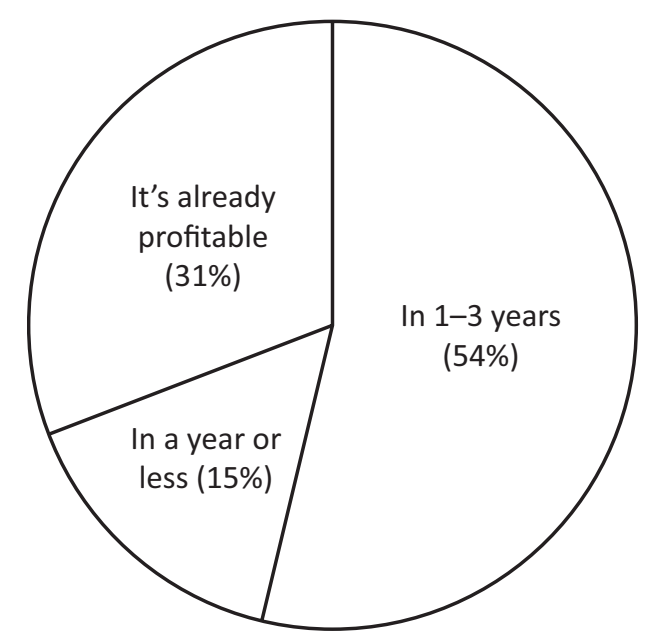

Figure 2. In what period of time do you think your podcast will become profitable? Source: Author's analysis. itable $(31 \%)$, or likely to become a lucrative business in the short- (15\%) or medium-term (54\%).

\section{Discussion and Conclusions}

The results of this case study confirm the abovementioned hypothesis: News native podcasts are still in an early phase of expansion and experimentation in Latin America, are a field of interest among entrepreneurs, are small in scale, and they are searching for business opportunities, new relationships with audiences, and strategic alliances with clients.

Moreover, the findings respond to our five research objectives. First, to understand and explore the degree of journalistic entrepreneurship reached by podcast projects in Latin America (RO1), results show that these news audio products provided by independent media outlets are in an early stage of development in the subcontinent. In the case of podcasts taken from the SembraMedia database (2019), 60\% of the projects were founded after 2014 and 92\% were created after 2010. Even so, the audio-only or audio-first news outlets only represent a mere $10 \%$ in this directory.

Likewise, news podcasting generates interest from journalistic entrepreneurs who search for opportunities to profit from the media sector while the number of direct competitors is still small. In this regard, findings also provide a greater understanding of the strategic planning approaches adopted by the promoters of these emergent journalistic projects regarding their business missions, their clients, and competitors (RO2).

The promoters of these new media highlight that these audio platforms are more oriented to the full exploitation of the narrative and innovative possibilities of this audio format and do not have responding to their target audiences' needs as their main priority. This fact suggests that further business training for entrepreneurial journalists may be necessary so that they can make their projects focused more on the examination of news opportunities in targeted audiences than in the use of new technologies. Fulfilment of the audiences' unmet needs is likely to occur irrespective of the medium or format employed to appeal to them.

Interestingly, three of these projects regard themselves as 'alternative media,' producing content especially addressed to minorities and covering topics and issues that are usually ignored by traditional media.

Besides, it is clear for the Latin American podcast providers that their audience is young, as observed by Newman (2019b). Despite this assumption, the strategic planning approaches adopted by these media exhibit a general lack of knowledge concerning their main target groups. This situation may impede not only their design and implementation of any news service but also their ability to reach advertisers and other clients.

These digital media assume they benefit from two advantages that distinguish them from competitors: occupying a market niche or offering a news service with a 
unique approach. In general, they perceive that there is a low level of competition.

To analyse the potential of podcasts to boost a journalists' personal brand ( $\mathrm{RO} 3$ ), it should be noted that none of the media outlets studied have been promoted just by one person. Thus, from this research, we cannot establish a direct connection between podcasting and the potential of this emergent medium to expand a journalists' personal brand. This is probably due to the fact that such professional podcasting involves greater technical complexity and more investment in technical equipment and, as a result, it may require the participation of a number of professionals.

In accordance with Toural and López (2019), the digital media outlets in this research use a combination of platforms to produce and disseminate news. The most frequently employed are Facebook and Twitter, followed by Instagram, YouTube, mobile apps, and newsletters.

The results of this study also point out some of the motivations that led entrepreneurs to news podcast production (RO4). While this audio format generates interest for its potential to innovate in narratives (Lindgren, 2016; Pérez \& Lus, 2019) or the opportunity to reach younger audiences, the promoters appear not to have considered all of the aspects outlined by scholars such as portability and synchrony (Salgado, 2010). On the contrary, they consider podcasts as having the potential to build new relationships with audiences by generating communities (González-Alba, 2018).

Regarding their business models and the chances of monetisation (RO5), the podcasters emphasized the relevance of diversifying revenue sources in order to ensure the viability of their entrepreneurships. Among the variety of ways these news media have found to monetise themselves, content production for clients (private companies or public institutions) is particularly important.

This result contrasts with the survey conducted by SembraMedia (2016) among digital media registered in its database. That study concluded that the main revenue sources for the new journalistic projects in Latin America were banners, native adverts or sponsored content, and consulting and training services. However, the monetisation of podcasts via subscriptions still seems to be difficult. This revenue source ranks in the sixth position according to the promoters' responses.

As usual in media companies, salaries earned by employees represent the most important expenditure item for these Latin American journalistic projects. It is encouraging that the podcasters interviewed consider their media are already profitable or may become lucrative within three years. This variety of income-generating activities may serve as a safeguard for these new media that have started to discover podcasts as a route to make journalism more profitable.

This article sheds light on news podcasting in Latin America which has been an underexplored area in journalism studies. It also outlines some editorial approaches and business models of audio digital media registered in the main directory of digital natives in the subcontinent to better understand an emerging phenomenon in Spanish-speaking markets.

However, some limitations of this study must be acknowledged. The first is related to the sample size. The reduced number of units of analysis makes it difficult to generalise the results, although the main goal of this case study is to provide key elements to explain a new and complex phenomenon.

The second limitation is a consequence of the geographic distance and the lack of physical accessibility to participants in the study. This prevented us from holding face-to-face interviews with entrepreneurial journalists to be able to carry out a more thorough analysis and gain in-depth knowledge about the research topic.

Further research is needed to better understand the emergent production and consumption of news podcasts in Latin American markets. On the one hand, this article will be complemented with an additional sub-study of the contents of each podcast provider in order to explore and compare their characteristics such as formats, topics, frequencies, and production routines. On the other hand, this research will need to be updated in three years since the digital media companies analysed assert they already are, or are going to be, profitable by the end of this period. Thus, further research will verify the evolution of these journalistic entrepreneurships and their strategic approaches.

\section{Acknowledgments}

The authors would like to thank anonymous reviewers for their valuable feedback and suggestions.

\section{Conflict of Interests}

The authors declare no conflict of interests.

\section{References}

Arrese, A., \& Kaufmann, J. (2016). Legacy and native news brands online: Do they show different news consumption patterns? International Journal on Media Management, 18(2), 75-97. https://doi.org/ 10.1080/14241277.2016.1200581

Berry, R. (2006). Will the iPod kill the radio star? Profiling podcasting as radio. Convergence: The International Journal of Research into New Media Technologies, 12(2), 143-162.

Berry, R. (2016). Podcasting: Considering the evolution of the medium and its association with the word 'radio.' Radio Journal: International Studies in Broadcast \& Audio Media, 14(1), 7-22. https://doi.org/10.1386/ rjao.14.1.7_1

Bonini, T. (2015). The "second age" of podcasting: Reframing podcasting as a new digital mass medium. Quaderns del CAC, 41(18), 21-30.

Bottomley, A. J. (2015). Podcasting: A decade in the life of 
a "new" audio medium: Introduction. Journal of Radio \& Audio Media, 22(2), 164-169. https://doi.org/ 10.1080/19376529.2015.1082880

Cabrera, M., Codina, L., \& Salaverría, R. (2019). Qué son y qué no son los nuevos medios. 70 visiones de expertos hispanos [What is new media? The views of 70 Hispanic experts]. Revista Latina de Comunicación Social, 74, 1506-1520. Retrieved from https://dadun. unav.edu/handle/10171/58737

Caro-González, F. J. (2007). Gestión de empresas informativas [Managing media companies]. Madrid: McGraw-Hill.

Caro-González, F. J., García-Gordillo, M. M., \& Bezunartea, O. (2014). Women and the press: Why so few women read newspapers. Estudios sobre el Mensaje Periodístico, 20(2), 987-1002. https://doi.org/ 10.5209/rev_ESMP.2014.v20.n2.47045

Demopoulos, T. (2006). What no one ever tells you about blogging and podcasting: Real-life advice from 101 people who successfully leverage the power of the blogosphere. Chicago, IL: Kaplan Pub.

De Vuyst, S., \& Raeymaeckers, K. (2017). Is journalism gender e-qual? A study of the gendered accumulation and evaluation of digital capital in journalism. Digital Journalism, 7(5), 554-570. https://doi.org/ 10.1080/21670811.2017.1369357

Djerf-Pierre, M. (2007). The gender of journalism: The structure and logic of the field in the twentieth century. Nordicom Review, 28, 81-104.

Edison Research. (2019). The podcasts consumer. Edison Research. Retrieved from https://www. edisonresearch.com/the-podcast-consumer-2019

Eisenhardt, K. M. (1989). Building theories from case study research. Academy of Management Review, 14(4), 532-550. https://doi.org/10.2307/258557

Eisenhardt, K. M., \& Graebner, M. (2007). Theory building from cases: Opportunities and challenges. Academy of Management Journal, 50(1), 25-32. https://doi.org/10.5465/amj.2007.24160888

González-Alba, J. A. (2018). El auge del pódcast como nueva narrativa periodística [The boom of podcasting as a new narrative in journalism]. Cuadernos de Periodistas, 2018(37), 85-99.

Grey, G. (2019). Top growing podcasting countries. Voxnest. Retrieved from https://blog.voxnest.com/ top-growing-podcasting-countries-march-2019

Gummesson, E. (2000). Qualitative methods in management research. London: Sage

Harlow, S., \& Salaverría, R. (2016). Regenerating journalism: Exploring the "alternativeness" and "digitalness" of online-native media in Latin America. Digital Journalism, 4(8), 1001-1019. https://doi.org/ 10.1080/21670811.2015.1135752

Hartley, J. (1994). Case studies in organisational research. In C. Cassell \& G. Symon (Eds.), Qualitative methods in organisational research (pp. 208-229). London: Sage.

Jenkins, H., Ford, S., \& Green, J. (2015). Cultura trans- media: La creación del contenido y valor en una cultura en red [Transmedia culture: Creating content and value in a networked culture]. Barcelona: Gedisa.

Lindeberg, A. (2019). So you have a podcast? What broadcasters and newspapers are doing with new forms of audio. Oxford: Reuters Institute for the Study of Journalism.

Lindgren, M. (2016). Personal narrative journalism and podcasting. Radio Journal: International Studies in Broadcast \& Audio Media, 14(1), 23-41. https://doi. org/10.1386/rjao.14.1.23_1

López-Meri, A., \& Casero, A. (2017). Las estrategias de los periodistas para la construcción de una marca personal en Twitter: Posicionamiento, curación de contenidos, personalización y especialización [Journalists' strategies to build a personal brand on Twitter: Positioning, content curation, personalisation and specialisation]. Mediterranean Journal of Communication, 8(1), 59-73. http://dx.doi.org/10.14198/ MEDCOM2017.8.1.5

Masip, P., Ruiz-Caballero, C., \& Suau, J. (2019). Active audiences and social discussion on the digital public sphere. Review article. El Profesional de la Información, 28(2), 1-40. https://doi.org//10.3145/epi.2019. mar.04

McClung, S., \& Johnson, K. (2010). Examining the motives of podcasts users. Journal of Radio \& Audio Media, 17(1), 82-95. https://doi.org/10.1080/ 19376521003719391

Miles, M., \& Huberman, A. M. (1994). Qualitative data analysis (2nd ed.). Beverly Hills, CA: Sage.

Moreno-Cazalla, L. (2017). Podium podcast, cuando el podcasting tiene acento español [Podium podcast, when Podcasting has Spanish accent]. Prisma Social: Revista de Investigación Social, 2017(18), 334-364.

Newman, N. (2018a). The future of voice and the implications for news. Oxford: Reuters Institute for the Study of Journalism.

Newman, N. (2018b). Podcasts and new audio strategies? In N. Newman, R. Fletcher, A. Kalogeropoulos, D. A. Levy, R. \& Kleis-Nielsen (Eds.), Digital news report 2018 (pp. 54-57). Oxford: Reuters Institute for the Study of Journalism.

Newman, N. (2019b). Podcasts: Who, what, why, and where. In N. Newman, R. Fletcher, A. Kalogeropoulos, D. A. Levy, R. \& Kleis-Nielsen (Eds.), Digital news report 2019 (pp. 60-64). Oxford: Reuters Institute for the Study of Journalism.

Newman, N., \& Gallo, N. (2019). News podcasts and the opportunities for publishers. Oxford: Reuters Institute for the Study of Journalism.

Pavlik, J. V. (2001). Journalism and new media. New York, NY: Columbia University Press.

Pedrero, L. M., Barrios, A., \& Medina, V. (2019). Teenagers, smartphones and digital audio consumption in the age of Spotify. Comunicar, 27(60), 103-112. https://doi.org/10.3916/C60-2019-10

Pérez, M. P. M.-C., \& Lus, E. (2019). El éxito de los pod- 
casts de noticias y su impacto en los medios de comunicación digital [Daily news podcasts success and their impact on digital media]. Miguel Hernández Communication Journal, 10(2), 323-340. Retrieved from http://rev.innovacionumh.es/index.php? journal=mhcj\&page=article\&op=view\&path\%5B\% $5 \mathrm{D}=314$

Porter, M. (1980). Competitive strategy: Techniques for analyzing industries and competitors. New York, NY: Free Press.

Quinn, S. (2006). Convergent journalism: The fundamentals of multimedia reporting. New York, NY: Peter Lang.

Rojas-Torrijos, J. L. (2018). El potencial del podcast como formato para un periodismo deportivo hiperespecializado o de nicho [Podcasting potential as a format for a hyperspecialised and niche sports journalism]. Periodismo Deportivo de Calidad. Retrieved from http:// periodismodeportivodecalidad.blogspot.com/2018/ 11/el-potencial-del-podcast-como-formato.html

Rouco, F. (2019). Vivir del podcasting en España es posible pero también excepcional [Living on podcasting in Spain is possible but it remains the exception]. Revista Telos. Retrieved from https:// telos.fundaciontelefonica.com/vivir-del-podcastingen-espana-es-posible-pero-tambien-excepcional

Rowley, J. (2002). Using case studies in research. Management Research News, 25(1), 16-27. https://doi. org/10.1108/01409170210782990

Salaverría, R. (2019). Digital journalism. In T. P. Vos \& F. Hanusch (Eds.), The international encyclopedia of journalism studies (pp. 453-463). Hoboken, NJ: Wiley-Blackwell. https://doi.org/10.1002/ 9781118841570.iejs0189

Salaverría, R., \& Negredo, S. (2013). Caracterización de los cibermedios nativos digitales [Characterisation of native digital media]. In M. A. Cabrera (Ed.), Evolución de los cibermedios: De la convergencia digital a la distribución multiplataforma [Evolution of digital media: From digital convergence to multi-platform distribution] (pp. 175-180). Madrid: Fragua.

Salgado, C. (2010). Presencia, innovación y estrategias de producción de los podcasting en la radio pública y privada a través de su convergencia multimedia [Presence, innovation and podcasting production strategies in public and commercial radio through multimedia convergence]. In C. M. Herreros (Ed.), Desarrollos del periodismo en internet [Developments in online journalism] (pp. 128-146). Zamora: Comunicación Social.

Sánchez, C. (2017). Tendencias y formatos en la radio actual [Trends and formats in the current radio]. In J. L. Rojas Torrijos (Ed.), Periodismo deportivo de manual
[Sports journalism essentials] (pp. 157-180). Valencia: Tirant Humanidades.

Schanke, V. S., \& Ytreberg, E. (2009). Working notions of active audiences: Further research on the active participant in convergent media industries. Convergence: The International Journal of Research into New Media Technologies, 15(4), 383-390. https:// doi.org/10.1177/1354856509342339

Sellas, T. (2011). El podcasting: La (r)evolución sonora [Podcasting: The audio (r)evolution]. Barcelona: UOC.

SembraMedia. (2016). En busca de la sustentabilidad [In search of sustainability]. SembraMedia. Retrieved from http://data.sembramedia.org/modelos-denegocios/?lang=es

SembraMedia. (2017). Inflection point. Impact, threats, and sustainability. SembraMedia. Retrieved from http://data.sembramedia.org

SembraMedia. (2019). SembraMedia database. SembraMedia. Retrieved from http://data.sembramedia.org

Sullivan, J. L. (2019). The platforms of podcasting: Past and present. Social Media + Society, 5(4), 1-12. https://doi.org/10.1177/2056305119880002

Toural, C., \& López, X. (2019). Ecosistema de cibermedios en España: Tipologías, iniciativas, tendencias narrativas y desafíos [Digital media ecosystem in Spain: Typologies, projects, narrative trends, and challenges]. Salamanca: Comunicación Social.

Usher, N. (2019). \#JStudiesSoWhite: A reckoning for the future. Paper presented at the 7th Future of Journalism Conference, Cardiff University, Cardiff, UK.

Verdier, H. (2018, March 30). Hear all about it: How daily news podcasts became publishing's new hope. The Guardian. Retrieved from https://www.theguardian. com/tv-and-radio/2018/mar/30/hear-all-about-ithow-daily-news-podcasts-became-publishings-newhope

Voxnest. (2018, December 20). The state of the podcast universe report. Brooklyn, NY: Voxnest. Retrieved from https://blog.voxnest.com/the-state-ofthe-podcast-universe-report

We Are Social, \& Hootsuite. (2019). Global digital report 2019. New York, NY, and Vancouver: We Are Social and Hootsuite. Retrieved from https://wearesocial. com/global-digital-report-2019

Webster, J. G., \& Ksiazek, T. B. (2012). The dynamics of audience fragmentation: Public attention in an age of digital media. Journal of Communication, 62(1), 39-56. https://doi.org/10.1111/j.1460-2466. 2011.01616.x

Yin, R. K. (2009). Case study research: Design and methods. Thousand Oaks, CA: Sage. 


\section{COGITATIO}

\section{About the Authors}

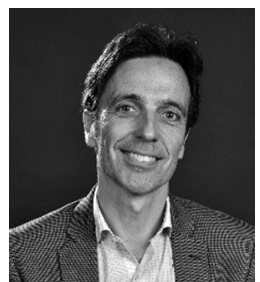

José Luis Rojas-Torrijos is a Lecturer in the Department of Journalism II at the University of Seville. He also participates in the MA programmes in journalism and sports communication at Pompeu Fabra University, the European University in Madrid, San Antonio Catholic University in Murcia, and Marca-CEU University. He holds a PhD in Journalism (2010) and a BA in Information Sciences (1994) from the University of Seville. His research focuses on sports journalism, ethics, stylebooks, and digital storytelling.

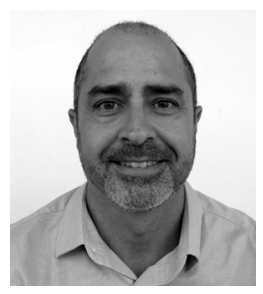

Francisco Javier Caro-González is Associate Professor in the Faculty of Communication at the University of Seville. He holds a PhD in Business Administration from the University of Seville (2002). He is a member of the Communication \& Social Sciences research group. He has been the Principal Researcher of the project R+D+I (2007-2010) "The Information Needs of Women." His research focuses on entrepreneurship journalism, organizational change, and media companies.

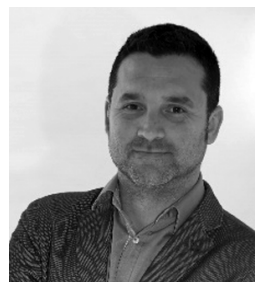

José Antonio González-Alba is a Researcher and a PhD Student in Communication from the University of Cádiz. He holds a BA in Journalism from the University of Seville and a MA in Innovation in Journalism from the Miguel Hernández University. His research focuses on digital transformation and innovation laboratories in media outlets. He is an expert in business communication and works as a Digital Transformation Trainer for media organisations. He is also the current Ambassador of SembraMedia in Spain. 